\title{
The Intricate Relationship between Melatonin and Breast Cancer: A Short Review
}

\author{
Lida Pistioli ${ }^{1,2,3^{*}}$, Dimitrios Katsarelias ${ }^{1,2,3}$, Riccardo A. Audisio ${ }^{1}$, Roger Olofsson Bagge ${ }^{1,2,3}$ \\ ${ }^{1}$ Department of Surgery, Institute of Clinical Sciences, Sahlgrenska Academy, University of Gothenburg, Gothenburg, Sweden \\ ${ }^{2}$ Department of Surgery, Sahlgrenska University Hospital, Gothenburg, Sweden \\ ${ }^{3}$ Wallenberg Centre for Molecular and Translational Medicine, University of Gothenburg, Sweden
}

${ }^{*}$ Corresponding author:

Lida Pistioli, MD

Department of Surgery Institute of Clinical Sciences

Sahlgrenska Academy University of Gothenburg

Gothenburg, Sweden

E-mail: lida.pistioli@vgregion.se

\section{Rezumat \\ Controverse asupra efectului melatoninei în cancerul de sân: un scurt review}

Melatonina este un hormon relativ recent izolat, produs de glanda pineală. Rolul său în numeroase functii celulare a atras atenția oamenilor de ştiință din întreaga lume. Există cercetări în curs care investighează efectul inhibitor al melatoninei asupra afecțiunilor maligne şi, în special, asupra cancerului de sân. Scopul acestui articol este de a discuta unele dintre cele mai importante descoperiri cu privire la efectele melatoninei asupra biologiei cancerului. Au fost analizate atât studii preclinice, cât şi clinice care oferă o perspectivă asupra acțiunilor biologice complexe ale acestei molecule, precum şi asupra semnificației şi implicaților aferente. Ultima parte se concentrează pe efectul oncostatic al melatoninei în cancerul de sân şi pune accent pe interactiunea dintre melatonină şi estrogen. Dovezile epidemiologice, experimentale şi clinice indică faptul că acest domeniu merită investigații suplimentare.

Cuvinte cheie: melatonină, particularitățile cancerului, cancerul de sân

\section{Abstract}

Melatonin is a relatively recently isolated hormone, produced by the pineal gland. Its implication in several cell functions has augmented interest from scientists worldwide. There is ongoing research investigating the deterrent relationship between 
melatonin and malignancies and in particular breast cancer. The aim of this article is to review some of the most important findings concerning the effect of melatonin on cancer biology, from both preclinical and clinical studies providing an insight to the complex biological actions of this molecule, as well as their potential significance. The last part concentrates on the oncostatic activities of melatonin on breast cancer and special attention is given on the interplay between melatonin and estrogen. Epidemiological, experimental and clinical evidence indicates that this area is worth further investigation.

Key words: melatonin, cancer hallmarks, breast cancer

\section{Introduction}

\section{Historical Background}

Melatonin was first isolated by Aaron Lerner and his associates from bovine pineal tissue back in 1958 (1). Being dermatologists, they were interested in identifying an, until then, unknown substance, that reversed the effect of melanocyte stimulating hormone in frog melanophores. And so, came the name of this newly discovered substance: Melatonin, from the Greek word melas (black/dark). At that time, little did they know about the multiple functions and the physiological importance of that small molecule.

From an evolutionary viewpoint, melatonin is a highly conserved molecule that has remained identical for almost 2.5 billion years (2). Its initial role was that of an anti-oxidant and free radical scavenger in ancestral proteobacteria and cyanobacteria and its synthesis was even at that time, light-dependent (3). According to the endosymbiotic hypothesis (4), primitive eukaryotes came to develop a symbiotic relationship with the engulfed purple non-sulfur bacteria and cyanobacteria, which later developed into mitochondria and chloroplasts, respectively. Evidence for the validity of this theory can be found in the fact that enzymes necessary for melatonin synthesis are found in both mitochondria and chloroplasts, where it is synthesized for local use. As the primitive cells evolved, the genes for the synthesis of melatonin were transferred to the nucleus. With the increasing complexity of multicellular organisms, a signaling molecule was required to convey information on diurnal variation and since melatonin production was already light-dependent, its use provided an elegant and practical solution to the problem. In developing animals this called for a centralized organ responsible for this function, i.e., the pineal (3).

\section{Anatomy and Physiology}

The pineal gland is a neuroendocrine organ, which develops as an outpouching of the dorsal midline of the diencephalon after neural tube closure (5). In the adult brain, it is located at the border of the diencephalon and the mesencephalon, under the splenium of the corpus callosum. The gland is surrounded by a capsule of conjunctival origin, with septa that separate the parenchyma into lobules and allows for the distribution of the vessels and nerves. The parenchyma consists of pinealocytes (which produce melatonin), interstitial cells, phagocytic cells and neurons. It might contain calcifications, which are visible on radiology and often referred to as "brain sand", and have a tendency to increase with age (6).

The pineal is considered a circumventricular organ, lacking blood-brain barrier and this is supported by experimental studies $(7,8)$. Blood supply comes mainly from the medial posterior choroidal arteries in the form of 1 to 3 slender branches that penetrate the gland parenchyma and in $30 \%$ of cases, the blood supply is unilateral. Venous drainage is complex and shows great variability, but the final vessel is the great cerebral vein of Galen (8). Since the pineal depends on external input for the regulation of melatonin secretion, its innervation is of 
particular importance and comprises of both sympathetic and parasympathetic input. The sympathetic fibers come from the superior cervical ganglion and constitute the final part of a neural pathway beginning in the retinal photoreceptors with a relay in the suprachiasmatic nucleus of the hypothalamus, where the master clock is located. Parasympathetic innervation originates through the sphenopalatine, the otic and the trigeminal ganglia (7). Destruction of the neural input turns the gland inactive (9). The pineal is not fully functional at birth, and so the fetus and the neonate depend on maternal melatonin through either the placenta or breastfeeding (10). The gland reaches its maximal size between the age of 5 and 7 (8).

Melatonin is an indole amine synthesized from the amino acid tryptophan (Fig. l) by all living cells, even though the pathways may vary among animals, plants and bacteria (11). Its biosynthesis in the pineal is regulated by sympathetic input, with the rate-limiting step catalyzed by serotonin- $\mathrm{N}$-acetyl transferase (SNAT), formerly called arylakylamine $\mathrm{N}$-acetyltransferase (AANAT) the activity of which exhibits a circadian oscillation which coincides with melatonin production $(11,12)$. Upon its production, it is directly released into the cerebrospinal fluid of the third ventricle

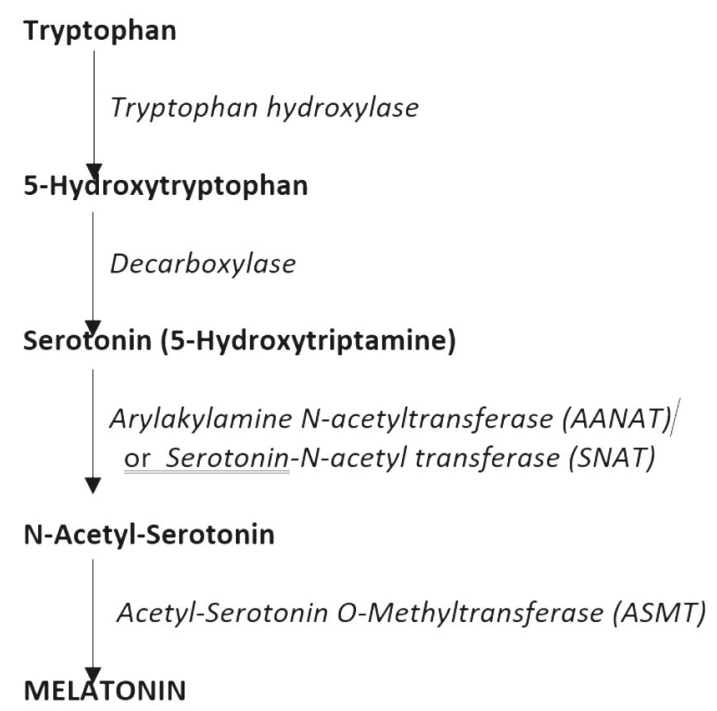

Figure 1. Biosynthesis of melatonin. The rate-limiting step is catalyzed by AANAT (SNAT) and the bloodstream. Its catabolism occurs mainly in the liver, where it is first transformed to 6-hydroxymelatonin by cytochrome P450 and then conjugated to 6-sulfatoxymelatonin, excreted by the urine (13).

The effects of melatonin on peripheral tissues are both receptor-mediated and receptor independent. Two types of melatonin membrane receptors have been identified: MT1 and MT2. Both are G protein-coupled receptors with $60 \%$ homology and can form homo and heterodimers once activated (14). Their activation leads to decreased cAMP and cGMP production and possibly increased diacylglycerol and IP3 production (13). Since the effect of melatonin and melatonin-related drugs are dependent on daytime and exposure duration, a diurnal sensitivity of its receptors has been hypothesized (15). Even though both receptors can be expressed by a single cell, one usually predominates e.g., MT1 in breast tissue. The result of receptor activation is both tissue and receptor dependent. Since melatonin is a lipophilic molecule than can penetrate cellular membranes, it can be found in the cytosol and the nucleus. A cytosolic receptor, formerly called MT3, has also been identified, to be later discovered that it is quinone reductase 2 (QR2), a potent anti-oxidant. Direct binding of melatonin to retinoid orphan receptors/ retinoid $\mathrm{Z}$ receptors (ROR/RZR) in the nucleus can inhibit the transcription of genes involved in cellular proliferation (13).

Contrary to what might be generally believed, melatonin is not exclusively produced by the pineal gland. Evidence for this comes both from its elevated concentration in certain tissues, when compared to plasma, but also from the isolation of melatonin synthesizing enzymes in those tissues. Extrapineal melatonin production does not appear to follow a circadian patten in all tissues, is not released into the circulation, and its functions are very much locus-dependent (16). Even though the pineal produces only a small part of the body's total melatonin, the end product has powerful results once released to the circulation. These are evident on both the organism as a whole and on the organ/cellular level. The most 
acknowledged is that of darkness signaling since synthesis of melatonin is inhibited by the visible light in the wavelength between 460-480 $\mathrm{nm}$ (blue light), during the day or, in the case of artificial light, at night (9). As such, it is intricately connected to sleep physiology and the regulation of peripheral circadian clocks. Together with this comes information about seasons, which is of particular importance for seasonal breeding animals, but no longer for humans.

Indirect evidence about the relationship between the pineal and puberty comes from the field of oncology. As early as 1898, the first report was published about a boy with precocious puberty and a pineal tumor. Several reports followed until in 1954 a review concluded that precocious puberty was associated with tumors in the region of the pineal, exerting pressure on the gland, whereas delayed puberty was associated with true pineal tumors (17). Abnormal pubertal manifestations are still considered a sign of pineal tumors (18). The effect of melatonin on ovarian function has also been studied in experimental animals showing inhibition of ovarian function (17). Melatonin production decreases with age, as indicated by experimental findings in humans (19).

On the tissue/cellular level, the effects of melatonin include that of anti-oxidant and free radical scavenging, both consistent with its ancestral role. This is in accordance with the already mentioned fact that almost $99 \%$ of its production occurs outside the pineal (mostly in the skin and gut) and remains on site for local use (3). There are several outstanding reviews on the multiple roles of melatonin $(2,9,20)$ but since their detailed analysis lies outside the scope of the current paper, we will briefly mention the most important of them which include detoxification, blood pressure modulation, protection against ischemia-reperfusion injury, enzyme regulation, anti-inflammatory effects, immunomodulation, reduction of drug toxicity, regulation of apoptosis, mitochondrial protection, anti-ageing effects and protection against neurodegeneration. Some of the above functions are in fact due to its free radical scavenging abilities and its high anti-oxidant capacities. However, it is the anti-cancer effects of melatonin that will be the focus of the rest of this paper, both against tumorigenesis, in general, and breast cancer, in particular.

\section{Melatonin and Cancer}

Cancer is a multifactorial disease and its initiation and progression require several steps. In 2000, Hanahan and Weinberg proposed six hallmarks, i.e., six distinct abilities required for the malignant transformation of cells. In 2011, another two were added by the same authors (21). Research findings point to the direction that melatonin has a negative impact on all proposed hallmarks, as follows:

\section{Uncontrolled Cellular Proliferation}

Control of cell division is under an intricate system involving oncogenes, tumor suppressor genes and cell cycle check points, to name a few. In cancer cells the balance is shifted towards uncontrolled division. In addition, the presence of nuclear aneuploidy indicates failure in cell cycle control. Prevention of DNA damage, promotion of DNA repair and inhibition of telomerase are proposed ways in which melatonin could contribute to the enhancement of genomic stability and cell cycle control. The direct anti-oxidant and free radical scavenging effect of melatonin acts as a shield against DNA damage (22). It has also been shown to increase DNA repair in $\mathrm{MCF}-7$ (breast cancer) and HCT-15 (colon cancer) cell lines by affecting gene expression of DNA repairing enzymes (23).

Telomerase is a nuclear enzyme that extends the ends of shortened chromosomes in dividing cells. This is important for chromosome stabilization. Telomerase inhibition, as demonstrated by in vitro and in vivo experiments is an additional effect of melatonin against cellular proliferation (24). Downregulation of cyclins and cyclin-dependent kinases by melatonin, in various experimental cancer cell lines, is an additional way of slowing down or arresting the cell cycle (21). Last but not least, interaction with estrogen 
biosynthesis and the estrogen signaling pathway (25) is a further function, of particular interest in breast cancer, which will be analyzed later on.

\section{Avoidance of Anti-growth Signaling}

Mutations in tumor suppressor genes are essential for the lack of response of cancer cells to anti-growth signaling. Melatonin treatment has been found to increase the expression of p53, BRCA1 and BRCA2 in cancer cell lines (21).

\section{Invasion and Metastasis}

Loss of cell contact by alterations in cellular junctions is linked with increased metastatic ability. Loss of E-cadherin, an important component of tight junctions, is one of the initial steps of the metastatic process. Melatonin treatment has been shown to increase E-cadherin expression (26). Integrin, a glycoprotein anchoring the cellular skeleton to the extracellular matrix, is also up-regulated with melatonin treatment $(21,26)$. Furthermore, the process of epithelial-mesenchymal transition, in which the epithelial cells shift to a mesenchymal phenotype with increased migratory potential, is also essential in the initiation and progression of metastasis. The process has been studied in breast cancer cell lines and melatonin treatment has been shown to hinder epithelial-mesenchymal transition, to reduce the viability of breast cancer stem cells and the expression of their surface markers (27).

\section{Replicative Immortality}

Refers to the capability of cancer cells to divide continuously. Telomerase, cyclins and cyclindependent kinases are involved in the process. As discussed, they are affected by melatonin treatment (24).

\section{Initiation of Angiogenesis}

The process of new blood vessel formation is essential for the provision of the tumor with oxygen and nutrients necessary for its growth. It also provides a route for metastasizing. When the tumor grows more than a few millimeters in diameter, hypoxia leads to the production of factors that promote angiogenesis (28). Tumors secrete angiogenic factors the most important of which include vascular endothelial growth factor (VEGF), epidermal growth factor (EGF) and platelet-derived growth factor (PDGF) and angiogenin. The inhibitory effect of melatonin on tumor-induced angiogenesis has been demonstrated both in vitro and in vivo animal experiments $(28,29)$.

\section{Apoptosis Resistance}

Tumor production of anti-apoptotic proteins helps cancer cells avoid programmed cell death. Melatonin treatment of both solid cancers (pancreatic, liver, murine gastric and prostate) as well as B-cell lymphoma, has been reported to induce apoptosis through various mechanisms (21). It is presumed that in physiological concentrations, melatonin has an oncostatic effect, mainly via cell cycle arrest, whereas the apoptotic outcome is achieved at higher concentrations (30). It has also been found that melatonin potentiates the apoptotic effect of docetaxel in breast cancer cell lines (31).

\section{Altered Tumor Metabolism}

Cancer cells have high metabolic demands. In 1924, O. Warburg first observed that cancer cells would preferentially metabolize glucose to lactate, even in the presence of adequate oxygen, choosing the anaerobic glycolysis pathway, instead of oxidative phosphorylation (32). This came to be called "aerobic glycolysis" or the "Warburg effect" and it was later shown that it is also carried out by normal proliferating cells as well. Since aerobic glycolysis provides a significantly lower ATP yield than oxidative phosphorylation, it does explain the rapid glucose uptake by the cancer, but one cannot help but question the biological advantage of such a shift. Warburg himself proposed 
defective mitochondrial function as a plausible explanation (32). Recent findings suggest that in some tumors, pyruvate transport into the mitochondria (and subsequent oxidative phosphorylation) is indeed hindered. Melatonin has been shown to promote pyruvate transport into the mitochondria in several solid tumors (33) and in the case of breast cancer, in particular, to reduce the magnitude of the Warburg effect during the nighttime (34).

\section{Escape from Immune Surveillance}

The ability of cancer cells to escape detection and subsequent destruction by the immune system has been acknowledged by research so far. Animal experiments involving mice with digestive/breast cancer have shown a shift in the immune response when treated with melatonin (21).

In addition to the above hallmarks, melatonin has also been shown to reduce carcinogenesis in states of chronic inflammation, mainly by interfering with reactive oxygen species and reactive nitrogen species that can cause DNA damage. Last but not least, melatonin can cause epigenetic changes in cancer cells, resulting in down-regulation of oncogenes (EGR3) and induction of tumor suppressor genes (GPC3) (30).

\section{Melatonin and Breast Cancer}

From its early discovery, the relationship between melatonin and ovarian function, as well as estrogen production led to numerous hypotheses regarding the role of the pineal in the onset of puberty and hormonal regulation. In 1978, M. Cohen proposed the melatonin hypothesis, stating that decreased production of melatonin, regardless of reason, could be a cause for the development of breast cancer (35). He postulated that decreased pineal function, and hence melatonin production, causes increased estrogen levels (and hence a state of "relative hyperestrogenism") since the inhibitory action of melatonin on the ovaries is lost. Since melatonin production decreases with age, this could be a possible factor contributing to the occurrence of breast cancer in the elderly. The first study to support this hypothesis was published a few years later, showing not only decreased plasma melatonin concentration in women with hormone receptor positive breast cancer, compared to controls, but also a correlation between the strength of hormonal positivity of the tumor and plasma melatonin concentration reduction (36). Altered rhythm of melatonin production has been reported in patients with breast cancer, among others, and the amount of the decrease in melatonin production was correlated to both tumor size and proliferation index (37). However, no matter how strong the correlation, no one could answer the question whether this change was brought about by the tumor, or if it really was one of the causes of tumorigenesis.

The concept of decreased pineal function because of technological advancements and the use of electricity in modern industrialized societies has also been a topic of considerable research. Light at night (LAN) permits the extension of human activities beyond daytime, allowing for shift work, and the use of cell phones and other light-emitting devices before going to sleep which can cause a decrease in melatonin production and interfere with sleepactivity patterns, and circadian regulation. Epidemiological studies not only suggest that breast and other hormone related cancers have an increased incidence in urban areas (although one could argue that this could be attributed to other factors, e.g. decreased access to diagnostic centers) but also an increased incidence in night shift workers.

The Nurses' Health Study examined the relationship between breast cancer incidence and nurses working on night shifts (38). A total of 78562 women were followed up for a period of 10 years. Information was also acquired about night shift work before the study period. The authors concluded that postmenopausal women who had been working on night shifts for more than 30 years had a considerably elevated risk for developing breast cancer compared to those who worked only during the day. Post-menopausal women 
showed an increase in breast cancer risk after 1-14 years of working in shifts. Circadian disruption and decreased melatonin production were discussed, in order to explain the findings. Several similar studies followed (3941) examining either shift work or light at night supporting the hypothesis of increased risk. In 2007 the International Agency for Research on Cancer, after reviewing the evidence, determined that "shift work that involves circadian disruption is probably carcinogenic to humans" and classified it as Group 2A ("probable") carcinogen (42). Of particular interest is the finding that blind women have a lower incidence of breast cancer $(43,44)$. This has been attributed to the fact that since totally blind women were unresponsive to visual light, melatonin production was not suppressed. Age of onset of total blindness (before age 65) was found to be of importance. On the other hand, partial blindness was not associated with an incidence decrease of the same magnitude.

Immunohistochemical staining of both normal and cancer breast tissue revealed the presence of melatonin receptors in both of them. As already stated, MT1 predominates in breast tissue. There is however a difference in the magnitude of expression, with normal tissue exhibiting weaker receptor intensity than cancerous tissue (45). A similar difference was also observed among the different breast cancer subtypes, with hormone receptor positive breast cancer staining stronger than triple negative cancer (46), as expected. Higher expression has been noted in HER2 positive, as opposed to HER2 negative tumors (45), a thought-provoking observation, given the proliferative effect of HER2. Lobular cancer had also weaker staining than ductal (47). The negative correlation between MT1 expression and Ki67 could be seen as a surrogate marker for melatonin's antiproliferative activity. A contradicting finding is that Jablonska et al showed an inverse correlation between MT1 expression and malignancy grade (45), whereas Dillon et al showed a positive correlation between the two (47). No significant association was found between receptor expression and patient age, menopausal status or tumor size.

Melatonin also plays a role in ovarian suppression and is involved in the onset of puberty. It is therefore logical to assume that its anti- estrogen effects could affect the growth of breast cancer, and especially hormone receptor positive breast cancer. This interplay between the two substances could be on multiple levels. By both direct action on the ovaries and indirect effects on the hypothalamic-gonadal axis, melatonin can downregulate estrogen biosynthesis. An effect consistent with the hypothesis of Cohen. Mechanisms about the influence of melatonin on the hypothalamic-gonadal axis have been suggested and a direct inhibitory effect on ovarian granulosa cells has been demonstrated, supporting this mode of action (25).

Furthermore, melatonin has been shown to act both on estrogen receptor and the estrogen synthesis. It inhibits the the estrogen receptor (ER) gene expression (48) and binding of the ER-estrogen composite to the estrogen response element of the DNA (25), acting as a selective estrogen receptor modulator (SERM). As a consequence, ER is blocked and estrogen cannot bind and exert its proliferative effects on ER+ breast cancer cells. This mechanism of action is similar to that of tamoxifen, the first anti-hormonal drug in the treatment of breast cancer. Support for these actions comes from breast cancer cell line research, especially the MCF-7 (hormone receptor positive) type. By inhibiting aromatase, it acts as a selective estrogen enzyme modulator (SEEM). Aromatase is an enzyme produced primarily in adipose tissue, which is responsible for the conversion of weak androgens produced by the adrenal glands, to estrogens. It constitutes the principal source of estrogens in post-menopausal women. Aromatase inhibition is the function of another category of antihormonal drugs for post-menopausal women with ER+ breast cancer. Experimental evidence demonstrates that melatonin decreases the activity of aromatase in the MCF-7 breast cancer cell line, both under normal conditions and when aromatase activity is enhanced (49). 
Studies on breast cancer cell lines have been able to provide proof for the antiproliferative and oncostatic effects of melatonin through the years. The majority of them have used, as expected, a hormone receptor positive cell line, namely MCF-7. The cell line was originally isolated from the pleural effusion of a breast cancer patient with generalized disease. It corresponds to the Luminal A subtype and represents the most studied breast cancer cell line (50). Treatment of those cells with melatonin, has been shown to decrease proliferation and increase apoptosis (51), inhibit aromatase synthesis and activity (49, $52,53)$, decrease metastatic potential of mammospheres (27) and reduce VEGF production and angiogenesis under hypoxic conditions (29). The latter has also been demonstrated on the MDA-MB-231 triple negative breast cancer cell line.

Melatonin has also been shown to decrease the epithelial-mesenchymal transition of breast cancer stem cells, decreasing their metastatic potential (51). Several studies have examined the synergistic effect of standard breast cancer treatments with melatonin, by pre-treating/incubating the cells with melatonin, before subjecting them to treatment. It was found that pretreatment increased the sensitivity of MCF-7 cells to ionizing radiation (54), that was attributed to the increase in p53 expression (55). Co-administration with doxorubicin led to increased MCF-7 apoptosis (51). A study investigating co-administration of continuous melatonin release and tamoxifen to MCF-7 cells showed a decrease in cell proliferation and increase in apoptosis (56). Five different tamoxifen-melatonin conjugates have been tested for their effects on MCF-7, tamoxifen-resistant MCF-7 and MDA-MB-231 cell lines. Two of them showed promising results in reducing cancer cell viability and future research in that field could provide novel adjuvant treatments for patients (57).

Animal experimental studies have tried to duplicate the effect of reduced melatonin production (via pinealectomy or prolonged illumination) as well as of enhanced melatonin production (by melatonin supplementation or reduced illumination) on breast cancer development and metastasis. Experiments show that pinealectomized/low melatonin production mice, when compared to enhanced melatonin production/supplementation, mice, have: 1) increased time lapse between induction of the carcinogen and emergence of the tumor, 2) lower tumor incidence, 3) reduced number and size of tumors, and 4) lower tumor growth rate (58). Furthermore, melatonin administration has been shown to increase the rate of spontaneous incidence of tumors in mice (37). The inhibitory effects of melatonin on breast cancer in animal models have been demonstrated on both hormone receptor positive and negative tumors. This implies that the anti-tumor effects of melatonin on breast cancer are not just restricted to its anti-estrogenic effects.

Compared to the number of in vitro and in vivo studies conducted so far, and in spite of the promising results, the number of clinical trials to investigate the effect of melatonin in cancer patients, is relatively small. In a recent systematic review and meta-analysis (59) a total of 20 randomized controlled trials were included, involving patients with any type of cancer confirmed by histology and having an interventional arm that included melatonin combined with some other, suitable treatment. The control arm would include patients receiving treatment without melatonin. Overall, the analysis showed that patients in the interventional arm, showed improved rates of remission, increased overall survival and at the same time, fewer chemotherapy- related side effects. Concerning breast cancer in particular, Lissoni et al, published two studies in 1995, including Stage IV patients. The first one involved patients $(n=14)$ with both estrogen receptor positive and negative metastatic breast cancer who were not eligible to conventional chemotherapy due to comorbidities, and were progressing under tamoxifen monotherapy (60). Four patients showed partial regression, while 2 showed disease progression and the remaining remained stable. No toxicity was reported. The second study involved patients with metastatic estrogen receptor negative breast $(n=40)$, not eligible for further 
chemotherapy, who were scheduled to receive tamoxifen (61). They were randomized to tamoxifen melatonin combination, or tamoxifen monotherapy. Partial response and survival at 1 year follow-up were found to be higher in the tamoxifen-melatonin group. Again, no melatonin-related toxicity was reported. Even though the studies are small, one cannot help but see some results that are worth further research, especially when the fact that melatonin itself is a drug of limited toxicity, is considered.

Taking into consideration the multiplicity of connections that exist between breast cancer and melatonin, investigating the potential of MT1 as a prognostic factor, could be of significance. A study investigating MT1 expression on all subtypes showed a positive correlation between high receptor expression and overall survival in the hormone receptor positive group. Further analysis indicated MT1 to be an independent prognostic factor for overall survival and disease-free survival in that group (45). A similar study investigating differential MT1 expression in triple negative breast cancer in African-American and Caucasian patients, concluded that the former had a greater incidence of MT1 negative tumors, which was linked to a higher hazard ratio for disease progression, and shorter overall survival (46). In a very recent publication, an attempt is made to use Acetylserotonin-O-Methyltransferase (ASMT), which catalyzes the last step in melatonin biosynthesis, as both a predictive and a prognostic factor. Based on the observation that ASMT was expressed in considerably smaller amounts in breast cancer as opposed to healthy tissue, and that its expression was correlated with improved relapse-free and metastasis free survival, the authors developed an ASMT gene signature that helps distinguish high from low-risk patients (62).

\section{Conclusions}

Melatonin is a fascinating hormone with multiple functions. In many countries it is easily accessible as an over-the-counter drug used as an aid for sleep disorders. Since its antitumoral effects have been recognized in several preclinical studies and extensive research has been conducted in order to clarify its functions it could possibly be used as an adjunct in the treatment of malignant conditions. Evidence is growing and both in vitro and clinical studies are still running. Among them, ongoing research at our Institution, is investigating the association of melatonin and breast cancer. We are addressing how melatonin could possibly affect prognosis in terms of both overall and disease-free survival. Although the research is ongoing, the intricate relationship between melatonin and cancer and more specifically breast cancer, could potentially result promising for our patients in the future.

\section{Conflict of Interest}

The authors declare no conflicts of interests.

\section{Ethics Approval}

Ethical approval was not required for the review article.

\section{Acknowledgment}

The authors would like to thank Alexandra Bolocan for her help in translating the Abstract in Romanian.

\section{References}

1. Lerner AB, Case JD, Takahashi Y. Isolation of melatonin and 5-methoxyindole3-acetic acid from bovine pineal glands. J Biol Chem. 1960:235:1992-7.

2. Tan DX, Hardeland R, Manchester LC, Paredes SD, Korkmaz A, Sainz RM, et al. The changing biological roles of melatonin during evolution: from an antioxidant to signals of darkness, sexual selection and fitness. Biol Rev Camb Philos Soc. 2010;85(3):607-23.

3. Zhao D, Yu Y, Shen Y, Liu Q, Zhao Z, Sharma R, et al. Melatonin Synthesis and Function: Evolutionary History in Animals and Plants. Front Endocrinol (Lausanne). 2019;10:249.

4. Sagan L. On the origin of mitosing cells. J Theor Biol. 1967;14(3): 255-74.

5. Kiecker $C$. The origins of the circumventricular organs. J Anat. 2018;232(4): 540-53.

6. Szathmari A, Jouvet A, Mottolese C, Champier J, Fevre Montange M: Anatomical, molecular and pathological consideration of the circumventricular organs. Neurochirurgie. 2015;61(2-3):90-100.

7. Moller M, Baeres FM. The anatomy and innervation of the mammalian pineal gland. Cell Tissue Res. 2002;309(1):139-50. 
8. Simon E, Afif A, M'Baye M, Mertens P: Anatomy of the pineal region applied to its surgical approach. Neurochirurgie. 2015; 61(2-3):70-76.

9. Reiter RJ, Tan DX, Galano A: Melatonin: exceeding expectations. Physiology (Bethesda). 2014:29(5):325-33.

10. Voiculescu SE, Zygouropoulos N, Zahiu CD, Zagrean AM. Role of melatonin in embryo fetal development. J Med Life. 2014;7(4):488-492.

11. Tan DX, Manchester LC, Esteban-Zubero E, Zhou Z, Reiter RJ. Melatonin as a Potent and Inducible Endogenous Antioxidant: Synthesis and Metabolism. Molecules, 2015;20(10):18886-18906.

12. Tan DX, Manchester LC, Liu X, Rosales-Corral SA, Acuna-Castroviejo D, Reiter RJ. Mitochondria and chloroplasts as the original sites of melatonin synthesis: a hypothesis related to melatonin's primary function and evolution in eukaryotes. J Pineal Res. 2013:54(2):127-138.

13. Amaral FGD, Cipolla-Neto J. A brief review about melatonin, a pineal hormone. Arch Endocrinol Metab. 2018;62(4):472-479.

14. Slominski RM, Reiter RJ, Schlabritz-Loutsevitch N, Ostrom RS, Slominski AT: Melatonin membrane receptors in peripheral tissues: distribution and functions. Mol Cell Endocrinol. 2012;351(2):152-66.

15. Dubocovich ML, Delagrange P, Krause DN, Sugden D, Cardinali DP, Olcese J. International Union of Basic and Clinical Pharmacology. LXXV. Nomenclature, classification, and pharmacology of $\mathrm{G}$ protein-coupled melatonin receptors. Pharmacol Rev. 2010;62(3):343-80.

16. Acuna-Castroviejo D, Escames G, Venegas C, Diaz-Casado ME, Lima-Cabello E, Lopez LC, et al. Extrapineal melatonin: sources, regulation, and potential functions. Cell Mol Life Sci. 2014;71(16):2997-3025.

17. Wurtman RJ, Axelrod J. The Pineal Gland. Sci Am. 1965;213:50-60

18. Rousselle $C$, des Portes V, Berlier P, Mottolese $C$. Pineal region tumors: Clinical symptoms and syndromes. Neurochirurgie. 2015;61(2-3):106-112

19. Sack RL, Lewy AJ, Erb DL, Vollmer WM, Singer CM: Human melatonin production decreases with age. J Pineal Res. 1986;3(4): 379-388.

20. Hardeland R, Cardinali DP, Srinivasan V, Spence DW, Brown GM, PandiPerumal SR. Melatonin--a pleiotropic, orchestrating regulator molecule. Prog Neurobiol. 2011;93(3):350-84.

21. Talib WH. Melatonin and Cancer Hallmarks. Molecules. 2018. 23(3):518.

22. Reiter RJ, Mayo JC, Tan DX, Sainz RM, Alatorre-Jimenez M, Qin L. Melatonin as an antioxidant: under promises but over delivers. J Pineal Res. 2016;61(3):253-278.

23. Liu R, Fu A, Hoffman AE, Zheng T, Zhu Y. Melatonin enhances DNA repair capacity possibly by affecting genes involved in DNA damage responsive pathways. BMC Cell Biol. 2013;14:1.

24. Mediavilla MD, Sanchez-Barcelo EJ, Tan DX, Manchester L, Reiter RJ. Basic mechanisms involved in the anti-cancer effects of melatonin. Curr Med Chem. 2010;17(36):4462-81.

25. Sanchez-Barcelo EJ, Cos S, Mediavilla D, Martinez-Campa C, Gonzalez A, Alonso-Gonzalez C. Melatonin-estrogen interactions in breast cancer. J Pineal Res. 2005:38(4):217-22.

26. Reiter RJ, Rosales-Corral SA, Tan DX, Acuna-Castroviejo D, Qin L, Yang SF, et al. Melatonin, a full service anti-cancer agent: inhibition of initiation, progression and metastasis. Int J Mol Sci. 2017; 18(4):843

27. Goncalves Ndo N, Colombo J, Lopes JR, Gelaleti GB, Moschetta MG, Sonehara NM, et al. Effect of melatonin in epithelial mesenchymal transition markers and invasive properties of breast cancer stem cells of canine and human cell lines. PLoS One. 2016; 11(3):e0150407.

28. Jardim-Perassi BV, Arbab AS, Ferreira LC, Borin TF, Varma NR, Iskander AS, et al. Effect of melatonin on tumor growth and angiogenesis in xenograft model of breast cancer. PLoS One. 2014; 9(1):e85311.

29. Jardim-Perassi BV, Lourenco MR, Doho GM, Grigolo IH, Gelaleti GB, Ferreira LC, et al. Melatonin regulates angiogenic factors under hypoxia in breast cancer cell lines. Anticancer Agents Med Chem. 2016;16(3):347-358.

30. Favero G, Moretti E, Bonomini F, Reiter RJ, Rodella LF, Rezzani R. Promising antineoplastic actions of melatonin. Front Pharmacol. 2018:9:1086.

31. Alonso-Gonzalez C, Menendez-Menendez J, Gonzalez-Gonzalez A, Gonzalez A, Cos S, Martinez-Campa C. Melatonin enhances the apoptotic effects and modulates the changes in gene expression induced by docetaxel in MCF7 human breast cancer cells. Int J Oncol. 2018:52(2):560-70

32. Vander Heiden MG, Cantley LC, Thompson CB. Understanding the Warburg effect: the metabolic requirements of cell proliferation. Science. 2009;
324(5930):1029-33

33. Reiter RJ, Sharma R, Rosales-Corral S. Anti-Warburg effect of melatonin: a proposed mechanism to explain its inhibition of multiple Diseases. Int J Mol Sci. 2021;22(2):764.

34. Hill SM, Belancio VP, Dauchy RT, Xiang S, Brimer S, Mao L, Hauch A, Lundberg PW, Summers W, Yuan L et al. Melatonin: an inhibitor of breast cancer. Endocr Relat Cancer. 2015;22(3):R183-204.

35. Cohen M, Lippman M, Chabner B: Role of pineal gland in aetiology and treatment of breast cancer. Lancet. 1978;2(8094):814-816.

36. Tamarkin L, Danforth D, Lichter A, DeMoss E, Cohen M, Chabner B, et al. Decreased nocturnal plasma melatonin peak in patients with estrogen receptor positive breast cancer. Science. 1982;216(4549): 1003-1005.

37. Grant SG, Melan MA, Latimer JJ, Witt-Enderby PA. Melatonin and breast cancer: cellular mechanisms, clinical studies and future perspectives. Expert Rev Mol Med. 2009:11:e5.

38. Schernhammer ES, Laden F, Speizer FE, Willett WC, Hunter DJ, Kawachi I, et al. Rotating night shifts and risk of breast cancer in women participating in the nurses' health study. J Natl Cancer Inst. 2001;93(20):1563-68.

39. Jones ME, Schoemaker MJ, McFadden EC, Wright LB, Johns LE, Swerdlow AJ. Night shift work and risk of breast cancer in women: the Generations Study cohort. Br J Cancer. 2019;121(2):172-9.

40. Menegaux F, Truong T, Anger A, Cordina-Duverger E, Lamkarkach F, Arveux $P$, et al. Night work and breast cancer: a population-based case-control study in France (the CECILE study). Int J Cancer. 2013;132(4):924-31.

41. Wegrzyn LR, Tamimi RM, Rosner BA, Brown SB, Stevens RG, Eliassen AH, et al. Rotating Night-Shift Work and the Risk of Breast Cancer in the Nurses' Health Studies. Am J Epidemiol. 2017; 186(5):532-540.

42. Cherrie JW. Shedding Light on the Association between Night Work and Breast Cancer. Ann Work Expo Health. 2019;63(6):608-11.

43. Feychting M, Osterlund B, Ahlbom A. Reduced cancer incidence among the blind. Epidemiology. 1998;9(5):490-494.

44. Kliukiene J, Tynes T, Andersen A. Risk of breast cancer among Norwegian women with visual impairment. Br J Cancer. 2001; 84(3):397-399.

45. Jablonska K, Pula B, Zemla A, Owczarek T, Wojnar A, Rys J, et al. Expression of melatonin receptor MT1 in cells of human invasive ductal breast carcinoma. J Pineal Res. 2013;54(3):334-345.

46. Oprea-llies G, Haus E, Sackett-Lundeen L, Liu Y, McLendon L, Busch R, et al. Expression of melatonin receptors in triple negative breast cancer (TNBC) in African American and Caucasian women: relation to survival. Breast Cancer Res Treat. 2013;137(3):677-87.

47. Dillon DC, Easley SE, Asch BB, Cheney RT, Brydon L, Jockers R, et al. Differential expression of high-affinity melatonin receptors (MT1) in normal and malignant human breast tissue. Am J Clin Pathol. 2002;118(3):451-58.

48. Amin N, Shafabakhsh R, Reiter RJ, Asemi Z. Melatonin is an appropriate candidate for breast cancer treatment: Based on known molecular mechanisms. J Cell Biochem. 2019;120(8):12208-12215.

49. Cos S, Martinez-Campa C, Mediavilla MD, Sanchez-Barcelo EJ: Melatonin modulates aromatase activity in MCF-7 human breast cancer cells. J Pineal Res. 2005;38(2):136-142.

50. Comsa S, Cimpean AM, Raica M: The Story of MCF-7 Breast Cancer Cell Line: 40 years of Experience in Research. Anticancer Res. 2015;35(6): 3147-3154.

51. Li Y, Li S, Zhou Y, Meng X, Zhang JJ, Xu DP, Li HB. Melatonin for the prevention and treatment of cancer. Oncotarget. 2017;8(24):39896-39921.

52. Knower KC, To SQ, Takagi K, Miki Y, Sasano H, Simpson ER, Clyne CD. Melatonin suppresses aromatase expression and activity in breast cancer associated fibroblasts. Breast Cancer Res Treat. 2012;132(2):765-771.

53. Martinez-Campa C, Gonzalez A, Mediavilla MD, Alonso-Gonzalez C, Alvarez-Garcia V. Sanchez-Barcelo EJ, et al. Melatonin inhibits aromatase promoter expression by regulating cyclooxygenases expression and activity in breast cancer cells. Br J Cancer. 2009; 101(9):1613-1619.

54. Alonso-Gonzalez C, Gonzalez A, Martinez-Campa C, Gomez-Arozamena J, Cos $S$. Melatonin sensitizes human breast cancer cells to ionizing radiation by downregulating proteins involved in double-strand DNA break repair. J Pineal Res. 2015:58(2):189-197.

55. Alonso-Gonzalez C, Gonzalez A, Martinez-Campa C, Menendez-Menendez J, Gomez-Arozamena J, Garcia-Vidal A, et al. Melatonin enhancement of the 
radiosensitivity of human breast cancer cells is associated with the modulation of proteins involved in estrogen biosynthesis. Cancer Lett. 2016;370(1):145-152.

56. Sabzichi M, Samadi N, Mohammadian J, Hamishehkar H, Akbarzadeh M, Molavi 0. Sustained release of melatonin: A novel approach in elevating efficacy of tamoxifen in breast cancer treatment. Colloids Surf B Biointerfaces. 2016;145:64-71.

57. Hasan M, Marzouk MA, Adhikari S, Wright TD, Miller BP, Matossian MD, et al: Pharmacological, Mechanistic, and Pharmacokinetic Assessment of Novel Melatonin-Tamoxifen Drug Conjugates as Breast Cancer Drugs. Mol Pharmacol. 2019;96(2):272-296.

58. Sanchez-Barcelo EJ, Cos S, Fernandez R, Mediavilla MD. Melatonin and mammary cancer: a short review. Endocr Relat Cancer. 2003;10(2): 153-159.
59. Wang $Y$, Wang $P$, Zheng $X$, Du $X$. Therapeutic strategies of melatonin in cancer patients: a systematic review and meta-analysis. Onco Targets Ther. 2018;11:7895-7908

60. Lissoni P, Barni S, Meregalli S, Fossati V, Cazzaniga M, Esposti D, et al. Modulation of cancer endocrine therapy by melatonin: a phase II study of tamoxifen plus melatonin in metastatic breast cancer patients progressing under tamoxifen alone. Br J Cancer. 1995;71(4):854-856.

61. Lissoni P, Ardizzoia A, Barni S, Paolorossi F, Tancini G, Meregalli S, et al. A randomized study of tamoxifen alone versus tamoxifen plus melatonin in estrogen receptor-negative heavily pretreated metastatic breast-cancer patients. Oncol Rep. 1995;2(5):871-3.

62. Tran QH, Than VT, Luu PL, Clarke D, Lam HN, Nguyen TT, et al. A novel signature predicts recurrence risk and therapeutic response in breast cancer patients. Int J Cancer 2021 Feb 14. 